\title{
Research on the Classified Training Mod- el of Peasants Distance Education
}

\author{
Lei Chen ${ }^{1}$ Xiaojing Zhang ${ }^{1}$ \\ ${ }^{1}$ Institute of Information on Science and Technology of Agriculture, Beijing Academy of \\ agriculture and forestry Sciences
}

\begin{abstract}
:
This paper analyzes three learning features of peasants distance education : highly dependent on technology, highly dependent on knowledge and highly dependent on interaction. This paper dissertates learning demands from five different groups of peasant: rural first-line manager, rural technical backbone, management and operation personnel, surplus labor force and labor force. On the basis of this, the anchors conduct research from three aspects on the classified training model of peasants distance education: technical support, learning resource and learning administration, and carry out analysis on selected sample for training improvement.
\end{abstract}

Keywords: classified training, distance education, peasants, training model

\section{Introduction}

With consideration both on current benefits and farsighted benefits, cultural quality, technical capacity and moral standard are key factors which determine the success of new rural construction and the speed of development of modern agriculture.

China's rural population is about 656.56million, made up around 48.7 per cent of the total population. According to the result of nationwide census conducted in 2010, among the current rural labor, $35 \%$ primary and secondary educational level, $40 \%$ junior high school education, less than $10 \%$ senior high school and Secondary vocational technical education, only $2 \%$ high school education.

According to the standard of building a well-off society in an all-round way which promoted by the relevant departments of the State Council, the per capita net income of rural resident household is 8000yuan, Engel coefficient is below $40 \%$. Compare to the above data, the per capita net income of rural resident household is 5919yuan, Engel coefficient is below $41.1 \%$ up to 2010 in China, a distance still exists and away from the welloff standard of living. Low overall competency of rural labor makes it difficult for agriculture development, for the growth of peasants' income, and the welloff construction process throughout the whole nation.

Training to peasants has become an important way to develop rural human capital. Rural audience has been divided into various groups due to differences on knowledge base, capability, development needs, role positioning and interests. Needs on rural training can no longer be met by single training model, distance education provide approaches to customized trainings to effectively overcome the problems on training time, content, system and funding. Economy, efficiency and convenience make distance education a major approach to future peasant training. 


\section{Characteristics of peasants distance education}

To provide trainings to peasants in modern distance education platform is part of Knowledge-intensive business service. Distance education needs to concentrate on audience's needs and expertise presentation, the rural audience would engage in the process of training curriculum design, material modification and knowledge implementation. It is a high interactive process between distance education platform and peasants users. Therefore, peasants distance education has the following characters:

\subsection{Highly dependent on technology}

The complicated network environment and high cost of distance education platform are widespread problems addressed in countryside. Therefore, stable and secured network environment is the first priority of developing distance education. The application of mobile streaming media technology, customized technical support, resource delivery technology, as well as a variety of technological approaches will be a future trend of distance education.

\subsection{Highly dependent on knowledge}

The presenting of knowledge and expertise is a distinct feature throughout the whole process of training inputs and training outputs. The providers of distance education training (e.g., rural expertise and platform administrator) usually possess specialized knowledge and accomplishment; training content includes knowledge and expertise in various areas.

\subsection{Highly dependent on interaction}

The ideal state of peasant distance training is to provide high-performance and customized training solution to rural users successfully, but this also requires active involvement of the rural users. So that interaction between rural users and distance education platform is crucial and highly required throughout the learning process.

\section{Peasants classification}

Considering the large base number of China' rural population, different level of educational achievement, we would take "applicable, practical and sufficient" as principles to conduct trainings to peasants. Peasants can be classified into five groups based on their roles in agricultural production.

\subsection{Rural first-line manager}

The rural first-line manager is represented by Party and government management cadres and college graduates villageofficial, they lead the way and play a management role in peasant trainings. They take the lead in study at various areas: political theories, culture, science and technology, market economy. By improving their own competences and enhancing their knowledge and management experience, they will be better to fit their roles and guide peasant masses to enrich their families and countries.

\subsection{Rural technical backbone}

Rural technical backbone refers to agriculture technician, experienced peasant and local expertise. They are the major force to promote door to door technical instruction, and to solve live production problems, so as to play the role of bridge and link. They are supposed to consistently engage in the agricultural science and technology training as well as agricultural skills training in order to contribute to rural masses and also to improve their own knowledge and skills. 


\subsection{Management and operation per- sonnel}

Management and operational personnel refers to the founder of professional agricultural cooperatives, managers, agriculture agents, etc. they are leaders of making the rural area becoming more prosperous. They undertake the historic mission of China's rural economic transition. They are required to equipped with various knowledge and competence, be familiar with the whole production procedure, and capable of combining and implementing all production resources.

\subsection{Rural surplus labor force}

Rural surplus labor force mostly indicates the so called "new generation" peasants who were born in the 1980's and 1990's, have been working in the local "township enterprise" or leaving for town for working opportunities, instead of take part in the agricultural production in countryside. They are also required to learn certain professional skills to qualify themselves in their positions.

\subsection{Rural labor force}

Rural labor force generally refers to the rural residents who directly engaged in agricultural production. This group is in large number and unskilled compare to other groups, it is also the most malleable group compare to others. Their changing will surely be able to make a decisive impact on agricultural production improvement. It is very important for the rural labor force to lay emphasis on strengthening agricultural basic knowledge and skills training, and to improve their science and technology accomplishment as well.

\section{The Classified Training Model}

\subsection{Technical support layer}

Technical support layer consists of net- work learning platform and mobile learning platform. Right after the peasant users login the distance education platform by category, learning resources will be recommended to them automatically to match the learning category they settled previously. Besides, the system will also filter duplicated resources automatically when peasant users login by new categories of identity, so learning resource won't be recommended to them repeatedly. Technical support layer is the basis of classified training of distance education.

\subsection{Resources support layer}

Resources support layers comprise basic knowledge layer, expertise knowledge layer and interest knowledge layer. Learning resource can also be classified and labeled in accordance with peasant users' categories. Basic knowledge layer contains the general learning content. Expertise knowledge layer provides a variety of professional learning content according to the characteristics of groups. Interest knowledge layer allows peasant users to select learning content by individual needs. Resources support is the core concept to develop classified training of distance education.

\subsection{Training administration supports layer}

Peasant users can make use of advisory services and the information aggregation function which provided by training administration support layer, to create customized learning plans. Advisory service provides resource to peasant users by means of video, audio, SMS and network. Information aggregation refers to the huge number of agricultural network resources gathered in the distance education platform, it is delivered to peasant users after information browsing, mining, encoding, collation and categorized. Training administration support is to guarantee 
the smooth operation of classified training of distance education.

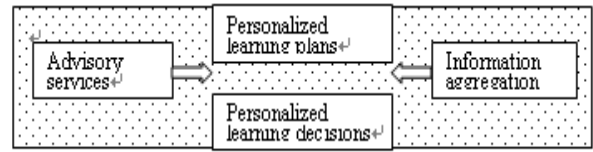

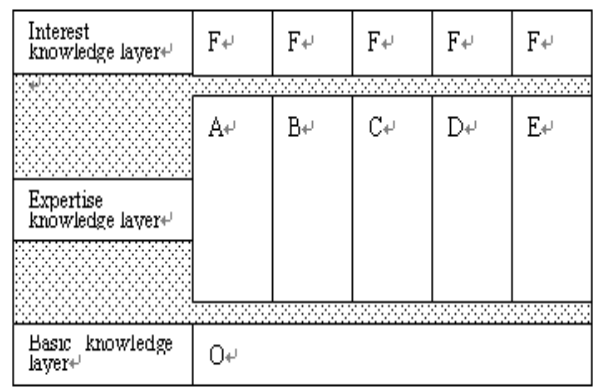

\begin{tabular}{|c|c|c|}
\hline $\begin{array}{l}\text { Network leamung } \\
\text { plattorm }\end{array}$ & & $\begin{array}{l}\text { Autormatic recommended } \\
\text { leamung resources }\end{array}$ \\
\hline 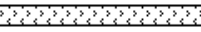 & & 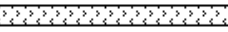 \\
\hline $\begin{array}{l}\text { Mobile leaming } \\
\text { plattorm }\end{array}$ & 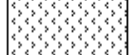 & $\begin{array}{l}\text { Automatic duplicated } \\
\text { leamung resource }\end{array}$ \\
\hline
\end{tabular}

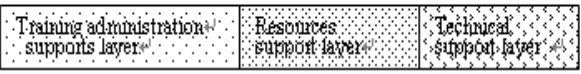

Fig. 1: The classified training model of peasant distance education

\section{5. the classified training sample analy- sis}

Beijing rural modern distance education platform has been selected as research sample. The platform officially launched in 2009. Until the end of July 2012, 17,315 video programs have been developed, 34,600 peasants registered as users and up to 4.07 million people have been trained, and the rural modern distance education platform and training team has been build up.

\subsection{Technical support to sample analysis}

To ensure the training system's maneuverability, technical support put emphasis on the development and application of a few key technologies. The platform is composed of learning resources broadcasting system, services and support systems, as well as training data pool.

Research and development focus has been placed on streaming media transmission technology and mobile education technology regarding broadcasting system; video diagnosis system, consulting service system by audio, intelligent information system as to service and support system; in response to the customized requirements from the users, research on resource construction plan and standardization has been carried out, live and on demand video, graphic and text resources are all able to be classified and integrated under guideline. In terms of software development, customized learning, mobile learning, decision-making support and Web portal have been completed. So that learning requirements are met on information automatic classification, demand automatic filter and interaction between users and platform.

\subsection{Resource to sample analysis}

To have trainings classified, resource is designed to encode by $\mathrm{O}_{i}, \mathrm{~A}_{\mathrm{i}}, \mathrm{B}_{\mathrm{i}}, \mathrm{C}_{\mathrm{i}}, \mathrm{D}_{\mathrm{i}}, \mathrm{E}_{\mathrm{i}}$ For example: i represents certain characteristic of classified role labels that are assigned from 1 according to the learning sequence or priority.

Resource code for general knowledge is as following: $\mathrm{O}_{1}$ refers to rural policy and regulations, $\mathrm{O}_{2}$ refers to basic law, $\mathrm{O}_{3}$ refers to agricultural production safety, $\mathrm{O}_{4}$ refers to rural living safety, $\mathrm{O}_{5}$ refers to application of agricultural information and network, $\mathrm{O}_{6}$ civil moral, etc.

As for the interest knowledge layer, peasant users can choose learning material to build their individual knowledge pool. 
Tab. 1: Resource code of expertise knowledge layer

\begin{tabular}{|c|c|}
\hline Type & Caracteristic of classified role labels (i) \\
\hline $\begin{array}{l}\text { Rural } \\
\text { first-line } \\
\text { Manager (A) }\end{array}$ & $\begin{array}{l}A_{1} \text { Party construction, } A_{2} \text { agricultural production } \\
\text { and operation, } A_{3} \text { the villagers management, } A_{4} \\
\text { the village management, } A_{5} \text { practical } \\
\text { writing, } A_{6} \text { mediation, } A_{7} \text { methods of work, } A_{8} \\
\text { typical experience }\end{array}$ \\
\hline $\begin{array}{l}\text { Rural } \\
\text { technical } \\
\text { backbone (B) }\end{array}$ & $\begin{array}{l}\mathrm{B}_{1} \text { Agricultural science and technology } \\
\text { knowledge, } \mathrm{B}_{2} \text { practical technology, } \mathrm{B}_{3} \text { the season } \\
\text { production, } \mathrm{B}_{4} \text { new breed new technology, } \mathrm{B}_{5} \\
\text { Plant management and disease prevention and } \\
\text { control, } \mathrm{B}_{6} \text { breed management and disease } \\
\text { prevention and control, } \mathrm{B}_{7} \text { promotion methods, } \mathrm{B}_{8} \\
\text { standards of service, } \mathrm{B}_{9} \text { team building, } \mathrm{B}_{10} \text { typical } \\
\text { experience }\end{array}$ \\
\hline $\begin{array}{l}\text { Management } \\
\text { and operation } \\
\text { persomel (C) }\end{array}$ & $\begin{array}{l}\mathrm{C}_{1} \text { Construction of organizational system, } \mathrm{C}_{2} \text { the } \\
\text { quality and safety of agricultural products, } \mathrm{C}_{3} \\
\text { Market negotiations, } \mathrm{C}_{4} \text { product marketing, } \mathrm{C}_{5} \\
\text { market knowledge, } \mathrm{C}_{6} \text { logistics management, } \mathrm{C}_{7} \\
\text { finance, } \mathrm{C}_{8} \text { accounting, } \mathrm{C}_{9} \text { typical experience }\end{array}$ \\
\hline $\begin{array}{l}\text { Rural surplus } \\
\text { labor force } \\
\text { (D) }\end{array}$ & $\begin{array}{l}\mathrm{D}_{1} \text { Occupation moral, } \mathrm{D}_{2} \text { economic and legal } \\
\text { knowledge, } \mathrm{D}_{3} \text { etiquette, } \mathrm{D}_{4} \text { safety in } \\
\text { production, } \mathrm{D}_{5} \text { domestic service class, } \mathrm{D}_{6} \text { health } \\
\text { care class, } \mathrm{D}_{7} \text { food and beverage (hotel) services } \\
\text { class, } \mathrm{D}_{8} \text { business marketing class, } \mathrm{D}_{9} \text { clothing } \\
\text { class, } \mathrm{D}_{10} \text { repair class, } \mathrm{D}_{11} \text { Property class, } \mathrm{D}_{12} \\
\text { mechanical and electrical class, } \mathrm{D}_{13} \\
\text { construction, } \mathrm{D}_{14} \text { typical experience }\end{array}$ \\
\hline $\begin{array}{l}\text { Rural labor } \\
\text { force (E) }\end{array}$ & $\begin{array}{l}\mathrm{E}_{1} \text { Crop varieties, } \mathrm{E}_{2} \text { Supporting cultivation, } \mathrm{E}_{3} \\
\text { Disaster mitigation, } \mathrm{E}_{4} \text { the quality and safety of } \\
\text { agricultural products, } \mathrm{E}_{5} \text { practical technology, } \mathrm{E}_{6} \\
\text { agricultural fertilizer seed, } \mathrm{E}_{7} \text { typical experience }\end{array}$ \\
\hline
\end{tabular}

\subsection{Training administration support to sample analysis}

At present, Beijing rural distance education platform has the model of "customized learning" and "decision-making support" being set up. With the implementation of "long distance video diagnosis" and "agricultural intelligent Question \& Answer (Q\&A) system", more and more customized learning plans have been generated based on classified learning resources. The training administration team provides services and support throughout the whole process of learning plan design, learning curriculum auto recommendation, user information record, learning status record, learning result record, display of excellent work and final learning summary. Information is now available by different forms such as visually learning status record, learning evaluation report and etc.

\section{Conclusions}

Considering the major characteristic of rural labor force and difference on training demands, this classified training model of peasant distance education is designed specifically for significant improvement of peasant training by using network learning resource, endeavor to meet knowledge and information requirements from rural masses, and strongly promote the development of rural information technology. In practice, according to the actual demand we may increase or modify the contents of the learning resources, even redesignate the peasants' groups and again match the appropriate learning resources.

\section{References)}

[1] Luo Haowen, He Qiyun, Huang Qiaojiao, "Study on Web-based Information Classification Standard of the Rural Labor Force," Chinese Agricultural Science Bulletin, pp. 280284, 2011, 27(30).

[2] Kim L. Niewolny, Patrick T. Lillard,'Expanding the boundaries of beginning farmer training and program development: A review of contemporary initiatives to cultivate a new generation of American farmers," Journal of Agriculture, Food Systems, and Community Development, pp. 65-88, 2010.

[3] http://www.stats.gov.cn/tjgb/ndtjgb/q gndtjgb/t20120222_402786440.htm 